Matgorzata Jaworek

\title{
KONDYCJA FINANSOWA PRZEDSIĘBIORSTW SPRYWATYZOWANYCH Z UDZIAŁEM KAPITAŁU ZAGRANICZNEGO W POLSCE
}

Z a ry s treści. W niniejszym artykule przedstawiono proces prywatyzacji przedsiębiorstw państwowych w Polsce, z udziałem kapitału zagranicznego, w latach 1990-2010. Zawarto w nim informacje o zakresie, dynamice i sytuacji finansowej przedsiębiorstw sprywatyzowanych pośrednio i bezpośrednio z udziałem kapitału zagranicznego. Artykuł powstał na podstawie informacji o procesach prywatyzacyjnych, pochodzących z baz danych Głównego Urzędu Statystycznego (GUS) i Ministerstwa Skarbu Państwa (MSP). Wykorzystano w nim także informacje uzyskane z prowadzonych przez GUS badań wyników finansowych przedsiębiorstw.

Słowa kluczowe: kapitał zagraniczny, prywatyzacja przedsiębiorstw państwowych, prywatyzacja bezpośrednia, prywatyzacja pośrednia.

\section{WSTEP}

Zagraniczni inwestorzy, lokując w Polsce swoje kapitały, w znacznym stopniu przyczynili się do budowy struktury własnościowej, która oparta jest na własności prywatnej. Uczestniczą w procesie przekształceń własnościowych przedsiębiorstw państwowych - prywatyzacji odgórnej, tzw. inwestycje brownfield. Jednocześnie tworzą od podstaw nowe podmioty gospodarcze - inwestycje greenfield i wpływają na przyspieszenie prywatyzacji oddolnej - założycielskiej. Emocje związane z udziałem inwestorów zagranicznych przybierały czasami postać demagogii, szczególnie w początkowym okresie prywatyzacji. Wynikało to z obawy o wyprzedaż za bezcen ,sreber rodowych”, z niepełnego rozpoznania zjawiska oraz oporu części pracowników prywatyzowanych podmiotów, będącego naturalną konsekwencją świadomości istniejących zagrożeń. Niemałe znaczenie odegrały także publicznie prezentowane opinie niektórych polityków, 
traktujących negację dorobku polskiej transformacji jako element „kapitału politycznego". Zarzucano inwestorom zagranicznym, że przejmują polskie przedsiębiorstwa celem ich późniejszej likwidacji. Wyrażano także opinie, że przedsiębiorstwa te nie wykazują zysku, aby nie płacić podatków.

$\mathrm{W}$ artykule podjęto próbę przedstawienia sytuacji finansowej przedsiębiorstw sprywatyzowanych pośrednio i bezpośrednio z udziałem kapitału zagranicznego na tle podmiotów sprywatyzowanych z kapitałem polskim.

\section{PRZEBIEG PROCESU PRYWATYZACJI W LATACH 1990-2010}

W badanym okresie prywatyzacją objęto 7534 przedsiębiorstw państwowych, z tego 1750 skomercjalizowano, 2193 poddano prywatyzacji bezpośredniej, 1937 postawiono w stan likwidacji z przyczyn ekonomicznych, a 1654 stanowiły zlikwidowane państwowe przedsiębiorstwa gospodarki rolnej, których mienie przejęła Agencja Nieruchomości Rolnych. Najwięcej przedsiębiorstw objęto przekształceniami własnościowymi w początkowym okresie transformacji. Przykładowo w latach 1990-1991 przekształcono 1258 przedsiębiorstw, natomiast w roku 1992 aż 1402 podmioty. W kolejnych latach ich liczba malała - do 35 przedsiębiorstw w roku 2006. W 2010 roku procesem przekształceń objęto tylko 18 podmiotów. W całym okresie prywatyzacji dominującą grupę stanowiły podmioty zajmujące się przetwórstwem przemysłowym - 43,6\%. Od 1990 roku najwięcej przedsiębiorstw objęto procesem przekształceń własnościowych w województwach: śląskim - 823, mazowieckim - 714, dolnośląskim - 519 i wielkopolskim - 504 (GUS, 2011, s. 27,8).

\section{UDZIAŁ INWESTORÓW ZAGRANICZNYCH W PRYWATYZACJI POŚREDNIEJ*}

Według danych Głównego Urzędu Statystycznego na koniec grudnia 2010 roku sprywatyzowano pośrednio 505 jednoosobowych spółek Skarbu Państwa. W 118 spółkach dokonano prywatyzacji z udziałem kapitału zagranicznego.

* Statystykę przekształceń własnościowych prowadzą na szczeblu centralnym dwie instytucje: Główny Urząd Statystyczny oraz Ministerstwo Skarbu Państwa (dawniej Ministerstwo Przekształceń Własnościowych - MPW). Dane liczbowe zawarte w publikacjach GUS oraz MSP różnią się od siebie. Do 1996 roku MPW podawało dane dotyczące generalnie tych przedsiębiorstw sprywatyzowanych, dla których organami założycielskimi byli wojewodowie oraz tych, wobec których 
Tabela 1. Prywatyzacja pośrednia jednoosobowych spółek Skarbu Państwa w latach 1990-2009 (stan na 31.12.2009)

\begin{tabular}{|c|c|c|c|c|c|c|c|c|c|c|c|}
\hline \multirow{2}{*}{ Wyszczególnienie } & \multicolumn{11}{|c|}{ Lata } \\
\hline & 1990 & 1991 & 1992 & 1993 & 1994 & 1995 & 1996 & 1997 & 1998 & 1999 & 2000 \\
\hline Liczba transakcji & $7 / 6$ & $23 / 22$ & $23 / 22$ & 48 & $40 / 36$ & $30 / 26$ & 24 & $46 / 44$ & 16 & $19 / 18$ & $24 / 21$ \\
\hline Oferty publicznej & 5 & 6 & 1 & 3 & 8 & 5 & 1 & 9 & 5 & 0 & 1 \\
\hline Przetargu publicznego & 0 & 0 & 0 & 0 & 0 & 0 & 3 & 22 & 7 & 11 & 8 \\
\hline Zaproszenia do negocjacji & 2 & 17 & 22 & 45 & 32 & 25 & 20 & 15 & 4 & 8 & 15 \\
\hline Inwestor strategiczny & 2 & 17 & 22 & 45 & 32 & 25 & 23 & 37 & 11 & 19 & 23 \\
\hline w tym: krajowy & 1 & 9 & 7 & 17 & 18 & 13 & 16 & 25 & 7 & 16 & 12 \\
\hline zagraniczny & 0 & 8 & 13 & 25 & 10 & 9 & 6 & 9 & 3 & 1 & 10 \\
\hline mieszany & 1 & 0 & 2 & 3 & 4 & 3 & 1 & 3 & 1 & 2 & 1 \\
\hline \multirow{2}{*}{ Wyszczególnienie } & \multicolumn{9}{|c|}{ Lata } & \multirow{2}{*}{\multicolumn{2}{|c|}{ Ogółem }} \\
\hline & 2001 & 2002 & 2003 & 2004 & 2005 & 2006 & 2007 & 2008 & 2009 & & \\
\hline Liczba transakcji & 32 & 21 & 6 & 10 & $6 / 7$ & 6 & 20 & 3 & 12 & \multicolumn{2}{|c|}{$417 / 399$} \\
\hline Oferty publicznej & 0 & 0 & 0 & 2 & 2 & 0 & 0 & 0 & 0 & \multicolumn{2}{|c|}{48} \\
\hline Przetargu publicznego & 11 & 4 & 0 & 1 & 0 & 0 & 1 & 1 & 0 & \multicolumn{2}{|c|}{69} \\
\hline Zaproszenia do negocjacji & 21 & 17 & 6 & 7 & 5 & 3 & 3 & 1 & 12 & \multicolumn{2}{|c|}{280} \\
\hline $\begin{array}{l}\text { Tryb niepubliczny } \\
\text { (wniesienie akcji SP) }\end{array}$ & & & & & & 3 & 16 & 1 & & \multicolumn{2}{|c|}{20} \\
\hline Inwestor strategiczny & 32 & 21 & 6 & 8 & 5 & 6 & 4 & 2 & 12 & \multicolumn{2}{|c|}{352} \\
\hline w tym: krajowy & 24 & 15 & 3 & 5 & 5 & 6 & 4 & 2 & 10 & \multicolumn{2}{|c|}{215} \\
\hline zagraniczny & 7 & 6 & 3 & 3 & 0 & 0 & 0 & 0 & 2 & \multicolumn{2}{|c|}{115} \\
\hline mieszany & 1 & 0 & 0 & 0 & 0 & 0 & 0 & 0 & 0 & \multicolumn{2}{|c|}{22} \\
\hline
\end{tabular}

Objaśnienia i uwagi: * W 18 spółkach zawarto podwójne transakcje, tj. sprzedaż w ofercie publicznej oraz inwestorowi strategicznemu.

Źródło: MSP (2011, s. 9).

W analizowanym okresie najwięcej spółek sprywatyzowanych pośrednio z udziałem kapitału zagranicznego powstało w województwach: mazowieckim - 22,0\%, wielkopolskim - 12,7\%, śląskim i dolnośląskim - 11,9\% (GUS, 2011, s. 31).

nadzór właścicielski wypełniało MPW. GUS swoimi danymi obejmuje wszystkie prywatyzowane przedsiębiorstwa państwowe i wszystkie jsSP. Obie instytucje w różny sposób pozyskują dane źródłowe: MSP na podstawie przeprowadzonych lub akceptowanych transakcji prywatyzacyjnych, GUS poprzez sprawozdawczość statystyczną od przedsiębiorstw i ich organów założycielskich. Tym samym dane na temat prywatyzacji pośredniej i udziału w niej inwestorów zagranicznych, zaprezentowane w niniejszym podrozdziale różnią się nieznacznie między sobą. 


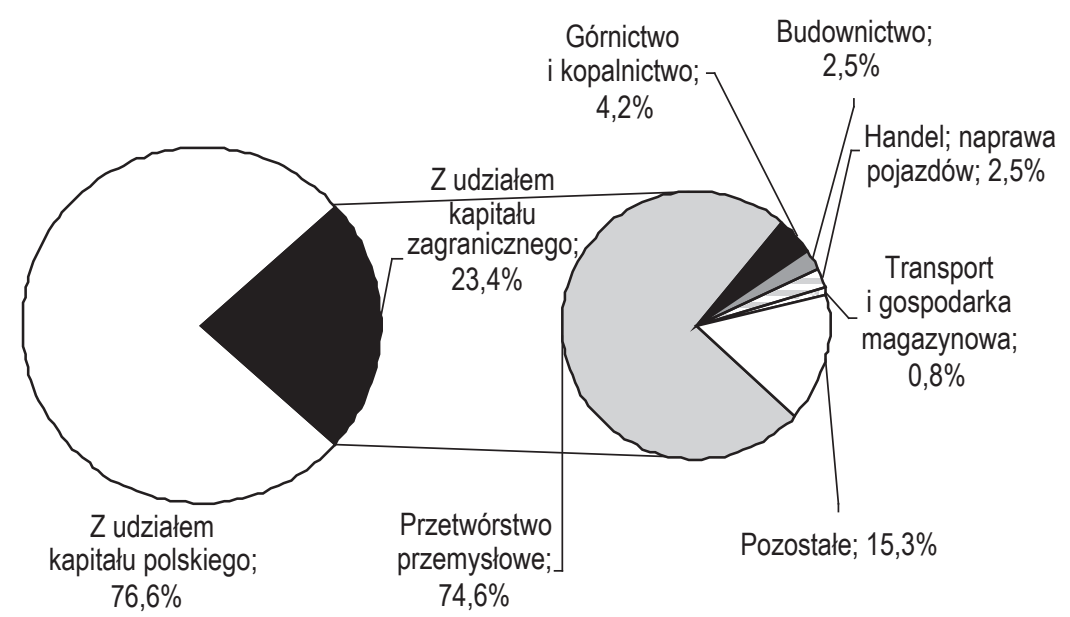

Wykres 1. Spółki sprywatyzowane pośrednio według sekcji i działów PKD (stan na 31.12.2010)

Źródło: opracowanie własne na podstawie: GUS, 2011, s. 52.

W tabeli 1 zaprezentowano informacje opracowane przez Ministerstwo Skarbu Państwa, dotyczące prywatyzacji pośredniej według stanu na koniec 2009 roku ${ }^{1}$. Według danych statystyki resortowej w 115 spółkach sprywatyzowanych pośrednio inwestorami strategicznymi byli inwestorzy zagraniczni, w 215 spółkach inwestorzy polscy, natomiast w 22 spółkach inwestorzy mieszani, w tym w 17 spółkach - zagraniczni z udziałem inwestorów polskich oraz w 5 spółkach inwestorzy mieszani zagraniczni.

Według stanu na koniec 2010 roku, w ścieżce prywatyzacji pośredniej najwięcej inwestorów zagranicznych uczestniczyło w przekształceniach przedsiębiorstw przetwórstwa przemysłowego $-74,6 \% \mathrm{~W}$ pozostałych działach inwestorzy zagraniczni nie przekroczyli 10\% udziału (wykres 1).

Najwięcej spółek z udziałem kapitału zagranicznego sprywatyzowano w województwach: mazowieckim -22,0\%, wielkopolskim - 12,7\% oraz dolnośląskim i śląskim po $11,9 \%$ (GUS, 2011, s. 53).

1 Niestety, MSP nie podało do wiadomości informacji za rok 2010, dotyczących szczegółowych danych na temat prywatyzacji pośredniej i udziału w niej inwestorów zagranicznych (według stanu na koniec 11.2011). 


\section{UDZIAŁ INWESTORÓW ZAGRANICZNYCH W PRYWATYZACJI BEZPOŚREDNIEJ (W TRYBIE WNIESIENIA PRZEDSIĘBIORSTWA DO SPÓŁKI)}

W latach 1990-2010 powstały 264 spółki z udziałem Skarbu Państwa, do których wniesiono majątek sprywatyzowanych bezpośrednio lub zlikwidowanych przedsiębiorstw państwowych. Z tej liczby w 59 przypadkach uczestniczył kapitał zagraniczny. Według stanu z dnia 31 grudnia 2010 roku działalność gospodarczą prowadziły nadal 152 spółki powstałe z wniesienia przedsiębiorstw państwowych, w tym 34 z udziałem inwestorów zagranicznych (GUS, 2011, s. 40).

Wśród powstałych tym trybem podmiotów, według stanu na koniec 2010 roku, 78,0\% stanowiły podmioty związane $\mathrm{z}$ przetwórstwem przemysłowym, 6,8\% z budownictwem, 6,8\% z górnictwem i kopalnictwem (wykres 2).

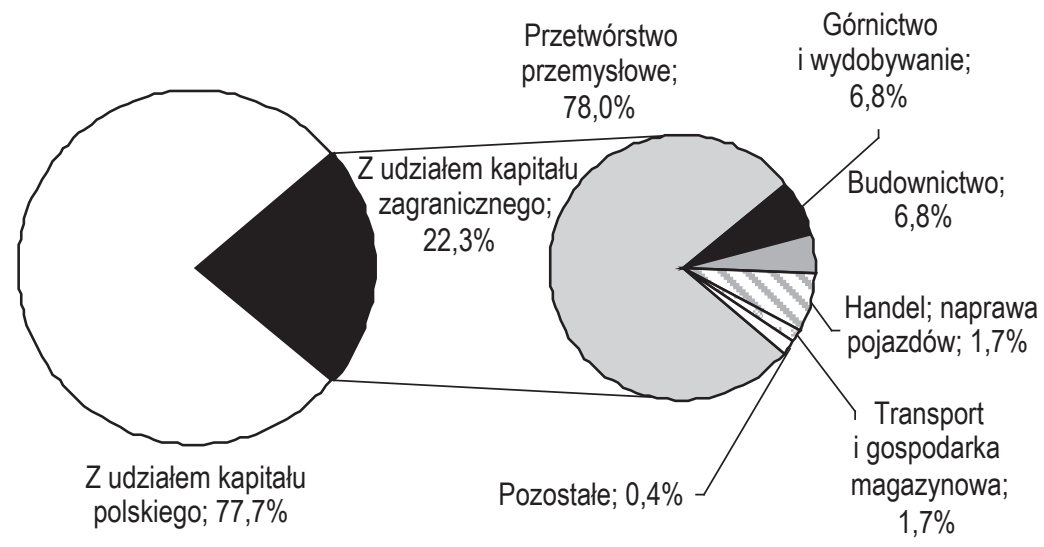

Wykres 2. Spółki z udziałem Skarbu Państwa powstałe z wniesienia majątku przedsiębiorstw państwowych według sekcji i działów PKD (stan na 31.12.2010)

Źródło: opracowanie własne na podstawie: GUS, 2011, s. 58.

Najwięcej spółek z udziałem kapitału zagranicznego powstało w województwach: wielkopolskim - 27,1\%, dolnośląskim - 15,3\% i mazowieckim po $10,2 \%$, świętokrzyskim - 8,5\% i zachodniopomorskim - 6,8\% (GUS, 2011, s. 58). 


\section{SYTUACJA FINANSOWA W RZEDSIĘBIORSTWACH SPRYWATYZOWANYCH Z UDZIAŁEM KAPITAŁU ZAGRANICZNEGO*}

W tabeli 2 zaprezentowano liczbę podmiotów, na podstawie której dokonano obliczenia prezentowanych parametrów finansowych. Liczby te nie pokrywają się z liczbą działających spółek, co może nieco zniekształcać obraz sytuacji finansowej badanych podmiotów ${ }^{2}$. Na sytuację finansową analizowanych przedsiębiorstw należy patrzeć przez pryzmat ścieżek prywatyzacji. Zasadniczo prywatyzacja kapitałowa obejmuje przedsiębiorstwa duże, o dobrym standingu. Natomiast prywatyzacji bezpośredniej podlegają przedsiębiorstwa mniejsze.

W przedsiębiorstwach sprywatyzowanych pośrednio z udziałem kapitału zagranicznego zanotowano, w analizowanym okresie, wyższe wskaźniki poziomu kosztó $\mathrm{w}^{3}$ aniżeli w przedsiębiorstwach sprywatyzowanych pośrednio z kapitałem krajowym, z wyjątkiem lat 1998, 1999 i 2002. Odmiennie kształtowała się sytuacja $\mathrm{w}$ przedsiębiorstwach sprywatyzowanych bezpośrednio z udziałem inwestorów zagranicznych. Począwszy od 1996 roku do 2010, poziom kosztów był niższy niż w przedsiębiorstwach z rodzimym kapitałem, przekształconych tą ścieżką, z wyjątkiem lat 1998 i 2004. W przedsiębiorstwach sprywatyzowanych w wyniku wniesienia majątku przedsiębiorstw państwowych do spółki z udziałem kapitału zagranicznego wskaźnik poziomu kosztów wyniósł w 2010 roku $95,0 \%$ i był to najwyższy poziom, począwszy od roku 2002. W badanym okresie nigdy jednak nie przekroczył poziomu 100\%. Porównując spółki z udziałem kapitału zagranicznego sprywatyzowane pośrednio i bezpośrednio, należy zauważyć, że pierwsza grupa wykazywała w badanym okresie wyższe wskaźniki poziomu kosztów, z wyjątkiem pierwszych czterech i dwóch ostatnich lat analizy. W roku 2010 najniższy poziom tego wskaźnika, wśród wszystkich analizowanych podmiotów, zanotowano w przedsiębiorstwach sprywatyzowanych pośrednio z kapitałem krajowym. Wskaźnik wyniósł w tych spółkach 89,0\% (tabela 3).

* W niniejszym podrozdziale analizie poddano lata 1998-2010 dla liczby badanych podmiotów i odsetka podmiotów sprywatyzowanych, osiągających zysk brutto i netto, oraz lata 1996-2010 dla wskaźników: poziomu kosztów, płynności finansowej pierwszego stopnia oraz rentowności obrotu brutto i netto. Niestety, GUS nie podaje dla lat wcześniejszych informacji dotyczących tych parametrów.

2 Za przykład może służyć rok 2010, w którym w niezmienionej postaci funkcjonowało 85 przedsiębiorstw sprywatyzowanych pośrednio z kapitałem zagranicznym oraz 303 z kapitałem krajowym, natomiast badaniu podlegało kolejno: 76 i 275 podmiotów.

3 Zgodnie z metodyką przyjętą przez GUS wskaźnik poziomu kosztów stanowi relację kosztów uzyskania przychodów z całokształtu działalności do przychodów z całokształtu działalności. 


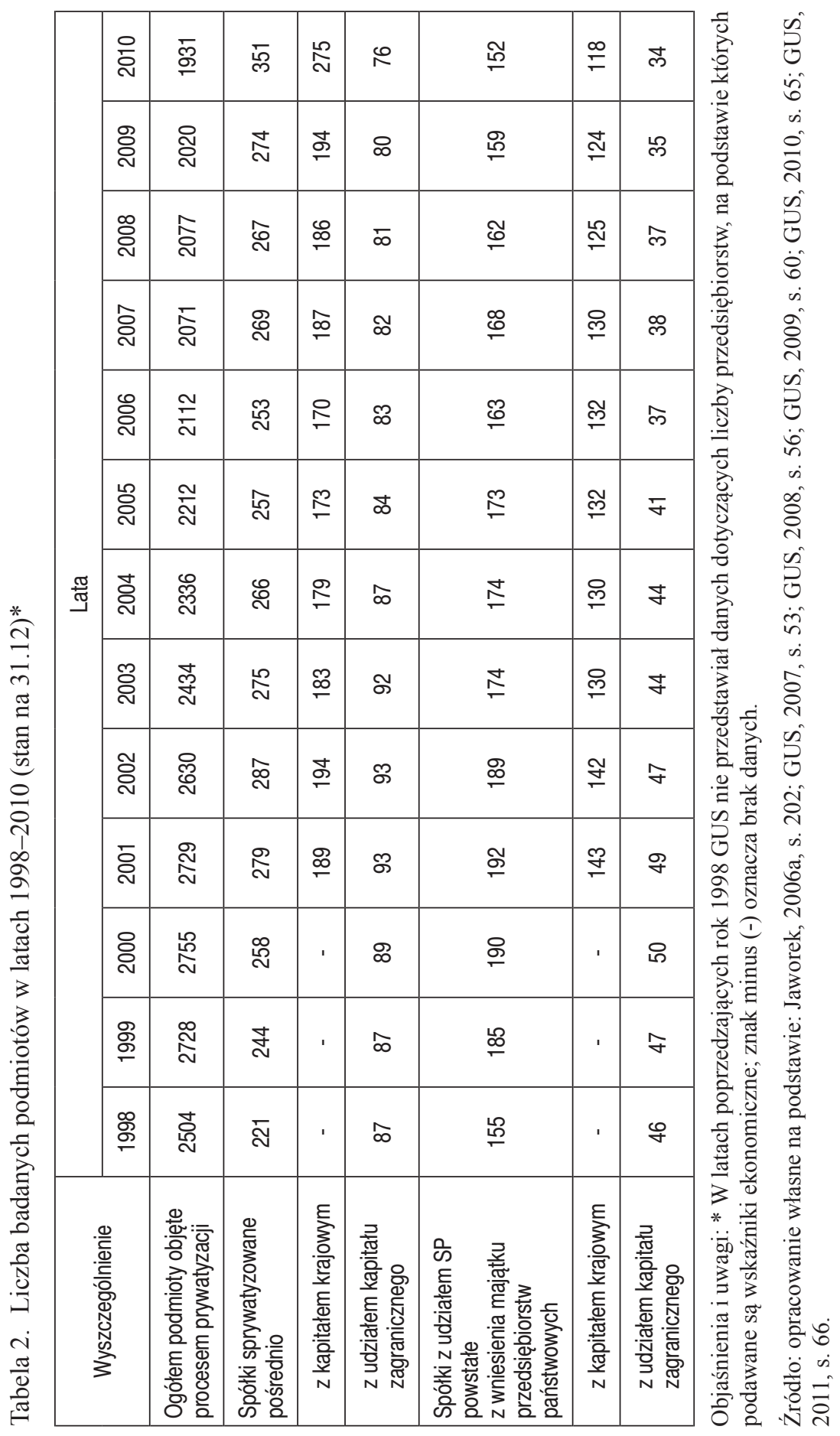




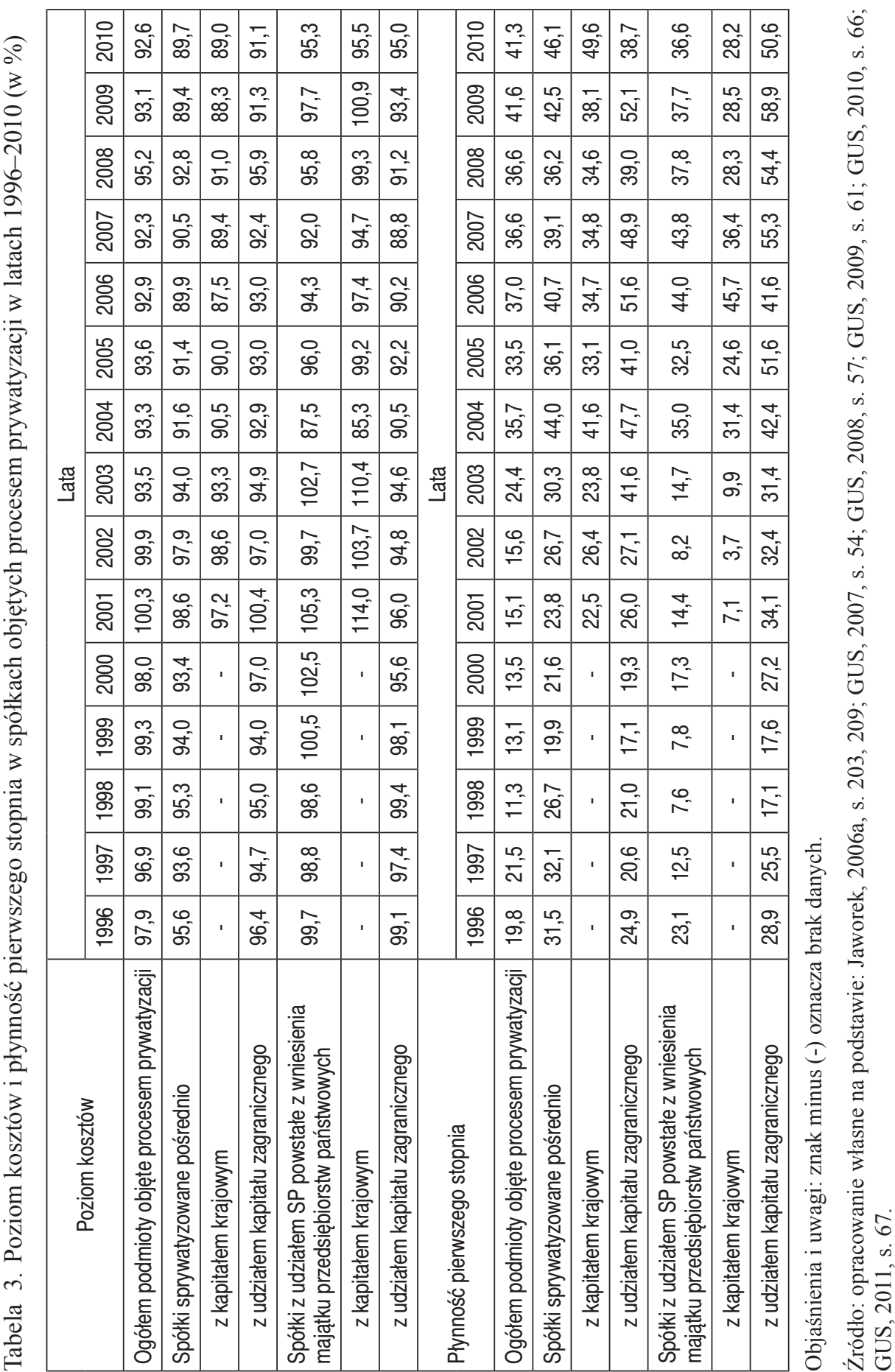


W latach 1996-2003 poziom płynności finansowej pierwszego stopnia ${ }^{4}$ w badanych podmiotach kształtował się na dość niskim poziomie. W latach 1996-1999 najwyższe poziomy wskaźnika wykazywały spółki sprywatyzowane pośrednio z kapitałem rodzimym, natomiast w latach 2000-2002, 2005 i 2007-2010 spółki powstałe z wniesienia mienia przedsiębiorstw państwowych z udziałem inwestorów zagranicznych. W latach 2003, 2004 i 2006 najwyższe poziomy tego wskaźnika osiągnęły spółki sprywatyzowane pośrednio z kapitałem zagranicznym.

W ostatnich siedmiu latach analizy, zasadniczo we wszystkich badanych grupach, wskaźnik oscylował powyżej 30\%. Wyjątek stanowiły podmioty sprywatyzowane bezpośrednio z udziałem kapitału krajowego. Od 2007 do 2010 roku najwyższe poziomy wskaźnika płynności pierwszego stopnia wykazywały podmioty sprywatyzowane bezpośrednio z udziałem kapitału zagranicznego. W całym badanym okresie osiągały one wyższe poziomy wskaźnika w porównaniu ze spółkami sprywatyzowanymi bezpośrednio z udziałem kapitału polskiego. W grupie przedsiębiorstw sprywatyzowanych pośrednio wyższe poziomy wskaźnika płynności pierwszego stopnia, w latach 2001-2009, wykazywały przedsiębiorstwa z udziałem inwestorów zagranicznych. Powód takiego stanu rzeczy może wynikać z przyjętej strategii inwestorów zagranicznych, polegającej m.in. na wydłużonym okresie spłaty zobowiązań i krótkim okresie ściągania należności (tabela 3). W okresie objętym analizą, z wyjątkiem lat 1998 i 2003, więcej spółek z udziałem kapitału zagranicznego sprywatyzowanych pośrednio wykazywało zysk brutto i, z wyjątkiem lat 1998, 2001-2003, zysk netto, w porównaniu ze spółkami sprywatyzowanymi z kapitałem krajowym.

Także w grupie przedsiębiorstw sprywatyzowanych bezpośrednio z udziałem inwestorów zagranicznych, w badanym okresie, więcej podmiotów osiągało zysk brutto i netto. Wyjątek stanowiły lata 1998, 1999 i $2002 \mathrm{w}$ odniesieniu do zysku brutto i lata 1998, 1999 w odniesieniu do zysku netto. W roku 2010, $\mathrm{w}$ porównaniu z rokiem poprzednim, we wszystkich badanych grupach odsetek podmiotów osiągających zysk spadł (tabela 4). Mimo że więcej podmiotów sprywatyzowanych pośrednio z udziałem kapitału zagranicznego wykazywało zysk, wskaźniki rentowności brutto i netto ${ }^{5}$ kształtowały się na niższym poziomie w porównaniu z przedsiębiorstwami sprywatyzowanymi tą ścieżką z kapitałem krajowym. Wyjątek stanowiły lata 1998, 1999 i 2002.

4 Zgodnie z metodyką przyjętą przez GUS wskaźnik płynności pierwszego stopnia stanowi relację inwestycji krótkoterminowych do zobowiązań krótkoterminowych.

5 Wskaźnik rentowności obrotu brutto obliczany jest jako stosunek wyniku finansowego brutto do przychodów z całokształtu działalności. Natomiast wskaźnik rentowności obrotu netto, jako stosunek wyniku finansowego netto do przychodów z całokształtu działalności. 


\begin{tabular}{|c|c|c|c|c|c|c|c|c|c|c|c|c|c|c|c|c|c|}
\hline 응 & $\begin{array}{l}\infty \\
\infty^{-}\end{array}$ & $\mid \begin{array}{l}10 \\
10 \\
0 \\
0\end{array}$ & $\mid \begin{array}{l}\infty \\
0 \\
6\end{array}$ & $\begin{array}{l}0 \\
\infty \\
\infty\end{array}$ & $\widetilde{\tilde{0}}$ & $\frac{9}{6}$ & $\left|\begin{array}{l}0 \\
0 \\
6\end{array}\right|$ & & 웅 & $\stackrel{+}{\circ}$ & $\mid$\begin{tabular}{|}
10 \\
10 \\
6
\end{tabular} & $\frac{10}{6}$ & $\begin{array}{c}m \\
\infty \\
\infty\end{array}$ & $\check{\mathscr{ర}}^{\infty}$ & ฮิ่ & $\begin{array}{l}0 \\
0 \\
0\end{array}$ & \\
\hline 유 & $\stackrel{0}{\circ}$ & $\left|\begin{array}{c}n \\
0 \\
N\end{array}\right|$ & N & $\left|\begin{array}{l}\infty \\
\tilde{\infty} \\
\infty\end{array}\right|$ & $\bar{T}$ & $\overrightarrow{8}$ & $\bar{N}$ & & ஓ్ণ & ठ্. & $\begin{array}{l}n \\
\stackrel{2}{N}\end{array}$ & $\frac{0}{1}$ & $\begin{array}{l}\infty \\
\infty \\
\infty\end{array}$ & $\bar{T}$ & $\begin{array}{l}+ \\
8 \\
8\end{array}$ & $\bar{N}$ & \\
\hline 유 & 交 & 年 & \begin{tabular}{|l|} 
\\
8 \\
8
\end{tabular} & $\begin{array}{l}m \\
\omega^{\infty}\end{array}$ & $\stackrel{0}{r}$ & $\begin{array}{l}\infty \\
\infty^{-} \\
\mathbb{b}\end{array}$ & $\frac{-}{\infty}$ & & 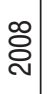 & $\mathfrak{N}^{2}$ & $\mid \begin{array}{l}\infty \\
\rho^{2} \\
\Gamma^{2}\end{array}$ & ब & 文 & $\stackrel{0}{\frac{1}{n}}$ & $\begin{array}{c}0 \\
80^{\circ} \\
0^{2}\end{array}$ & $\frac{\sigma}{\infty}$ & \\
\hline 今్ & $\begin{array}{l}\text { के } \\
\text { के }\end{array}$ & $\mid$ & $\bar{\Omega}$ & $\begin{array}{l}\tilde{8} \\
8\end{array}$ & $\stackrel{\infty}{\mathfrak{N}^{-}}$ & $\frac{1}{1}$ & $\frac{0}{\infty}$ & & 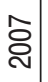 & ○ & $\frac{\sigma_{-}}{\infty}$ & $\bar{\infty}^{-}$ & 이 & $\begin{array}{c}\text { o } \\
\text { N }\end{array}$ & 임 & $\frac{0}{\infty}$ & \\
\hline రి & $\stackrel{m}{N^{2}}$ & $\overline{2}$ & $\mathbf{N}^{-}$ & $\overline{\check{\infty}}$ & $\bar{R}$ & \begin{tabular}{|l|}
$\tilde{N}^{\prime}$ \\
\end{tabular} & \begin{tabular}{l|}
$\infty$ \\
$\infty$ \\
$\infty$
\end{tabular} & & రి & $\widehat{\phi^{\circ}}$ & $\bar{N}$ & $\stackrel{0}{N}$ & $\frac{\infty}{\infty}$ & $\begin{array}{l}\infty \\
0 \\
0\end{array}$ & $\begin{array}{l}N \\
\stackrel{N}{N}\end{array}$ & $\begin{array}{l}\infty \\
\ddot{\infty}\end{array}$ & \\
\hline 옹 & 昗 & \begin{tabular}{l}
0 \\
\multirow{1}{*}{}
\end{tabular} & হ্ & $\mid \begin{array}{l}10 \\
\infty \\
\infty\end{array}$ & ̊ & 옴 & \begin{tabular}{c|}
0 \\
$N^{-}$ \\
$R$
\end{tabular} \mid & & 苂 & אִ & $\begin{array}{l}\hat{0} \\
\hat{n}^{\circ}\end{array}$ & @i & $\begin{array}{l}0 \\
\infty \\
\infty\end{array}$ & $=$ & $\begin{array}{l}0 \\
0 \\
2 \\
2\end{array}$ & ָ̃ & \\
\hline 茎 & 余 & $\mid \begin{array}{l}\mathfrak{N} \\
\mathfrak{N}\end{array}$ & న్ & $\mid \begin{array}{c}m \\
\sigma^{2}\end{array}$ & $\stackrel{\mathscr{N}}{\mathscr{N}}$ & $\begin{array}{l}\infty \\
\infty \\
0\end{array}$ & $\begin{array}{l}\infty \\
\infty \\
\infty\end{array}$ & 茎 & 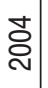 & 昗 & $\widehat{\hat{N}^{-}}$ & $\bar{N}$ & 엉 & $\stackrel{\mathscr{N}}{\sim}$ & $\begin{array}{l}\infty \\
\rho^{2}\end{array}$ & $\frac{\infty}{\infty}$ & \\
\hline ర్లి & 웅 & $\widehat{c}$ & $\frac{0}{1}$ & $\bar{\sigma}$ & $\overline{8}$ & $\begin{array}{l}0 \\
\tilde{\sigma}\end{array}$ & $\begin{array}{l}0 \\
0 \\
0 \\
0\end{array}$ & & రి & 잉 & $\begin{array}{l}m \\
\tilde{6} \\
\tilde{6}\end{array}$ & ন্் & ○- & $\tilde{\mathscr{E}}^{-}$ & $\begin{array}{l}\infty \\
0 \\
8 \\
8\end{array}$ & م & \\
\hline ণ్రి & in & $\begin{array}{l}m \\
0 \\
0\end{array}$ & $\mid \begin{array}{l}m \\
0 \\
10\end{array}$ & $\begin{array}{l}\stackrel{.}{~} \\
\tilde{\Xi}\end{array}$ & 㤐 & \begin{tabular}{|l|}
0 \\
$\infty$ \\
$\infty$ \\
10
\end{tabular} & $\begin{array}{l} \pm \\
5 \\
5\end{array}$ & & ণ్రి & $\begin{array}{l}\text { m } \\
6^{\circ}\end{array}$ & $\mid \begin{array}{l}10 \\
00^{\circ} \\
10\end{array}$ & \begin{tabular}{l}
$m$ \\
\multicolumn{1}{c}{}
\end{tabular} & $\begin{array}{l}0 \\
1 \\
10\end{array}$ & $\overline{6}$ & $\left|\begin{array}{c|}0 \\
5 \\
5 \\
5\end{array}\right|$ & in & \\
\hline চ్ర & 络 & $\begin{array}{l}10 \\
0 \\
5\end{array}$ & $\mid \begin{array}{l}\infty \\
\tilde{N} \\
{[}\end{array}$ & $\begin{array}{l}0 \\
10^{\circ} \\
{[م}\end{array}$ & $\begin{array}{l}m \\
\text { f }\end{array}$ & $\begin{array}{c}\mathscr{0} \\
\stackrel{-}{q}\end{array}$ & L' & & 유 & $\begin{array}{l}\dot{J} \\
\dot{0}\end{array}$ & $\begin{array}{l}0 \\
07 \\
10\end{array}$ & $\begin{array}{l}\widetilde{N} \\
\tilde{N}\end{array}$ & กิ & ָै & 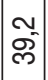 & 동 & \\
\hline ర్ల & 禹 & 命 & ' & $\begin{array}{l}\text { శ్ } \\
\text { ָే }\end{array}$ & ల్గా & . & $\begin{array}{l}0 \\
\infty \\
0^{\circ}\end{array}$ & & ర্ণ & $\begin{array}{l}\infty \\
\infty \infty^{-} \\
{[\infty}\end{array}$ & 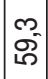 & ' & $\frac{\infty}{\sigma}$ & $\frac{6}{50}$ & . & $\begin{array}{l}0 \\
0 \\
10\end{array}$ & \\
\hline প্নে & $\frac{0}{6}$ & $\mid \begin{array}{c}0 \\
\tilde{8}^{0}\end{array}$ & ' & 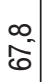 & E & . & $\begin{array}{l}n \\
\tilde{N} \\
\tilde{L}\end{array}$ & & ஓ্ & के & $\overline{\tilde{0}}$ & ' & $\begin{array}{l}10 \\
18 \\
8\end{array}$ & $\begin{array}{l}\tilde{\Omega} \\
\tilde{\Omega}\end{array}$ & . & 5 & 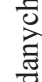 \\
\hline$\stackrel{\circ}{\stackrel{一}{-~}}$ & $\underset{\mathbb{6}}{\Delta}$ & $\mid \begin{array}{l}m \\
80^{\circ}\end{array}$ & ' & \begin{tabular}{|c|}
10 \\
10 \\
0
\end{tabular} & $\frac{m}{6}$ & . & 志 & & 足 & $\overline{8}$ & $\mid \begin{array}{l}0 \\
\hat{6}\end{array}$ & ' & $\begin{array}{l}+ \\
\dot{0}\end{array}$ & 宛 & ' & 离 & 5 \\
\hline 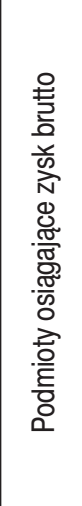 & 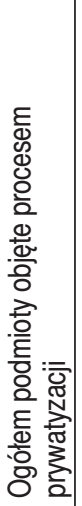 & 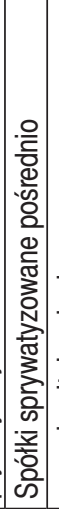 & 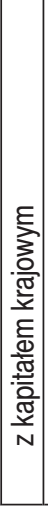 & 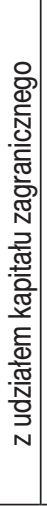 & 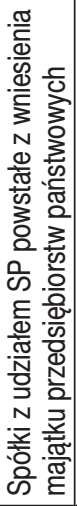 & 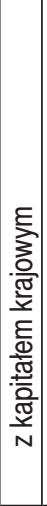 & 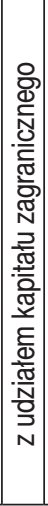 & 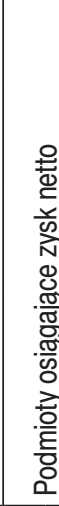 & 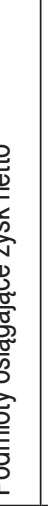 & 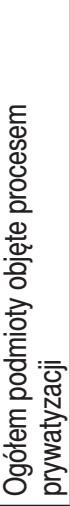 & 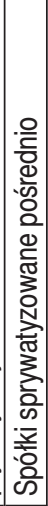 & 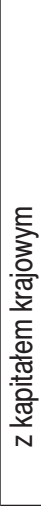 & 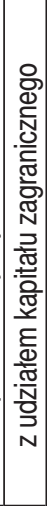 & 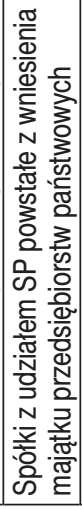 & 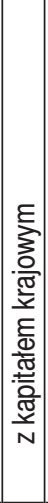 & 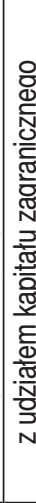 & 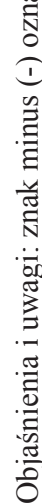 \\
\hline
\end{tabular}




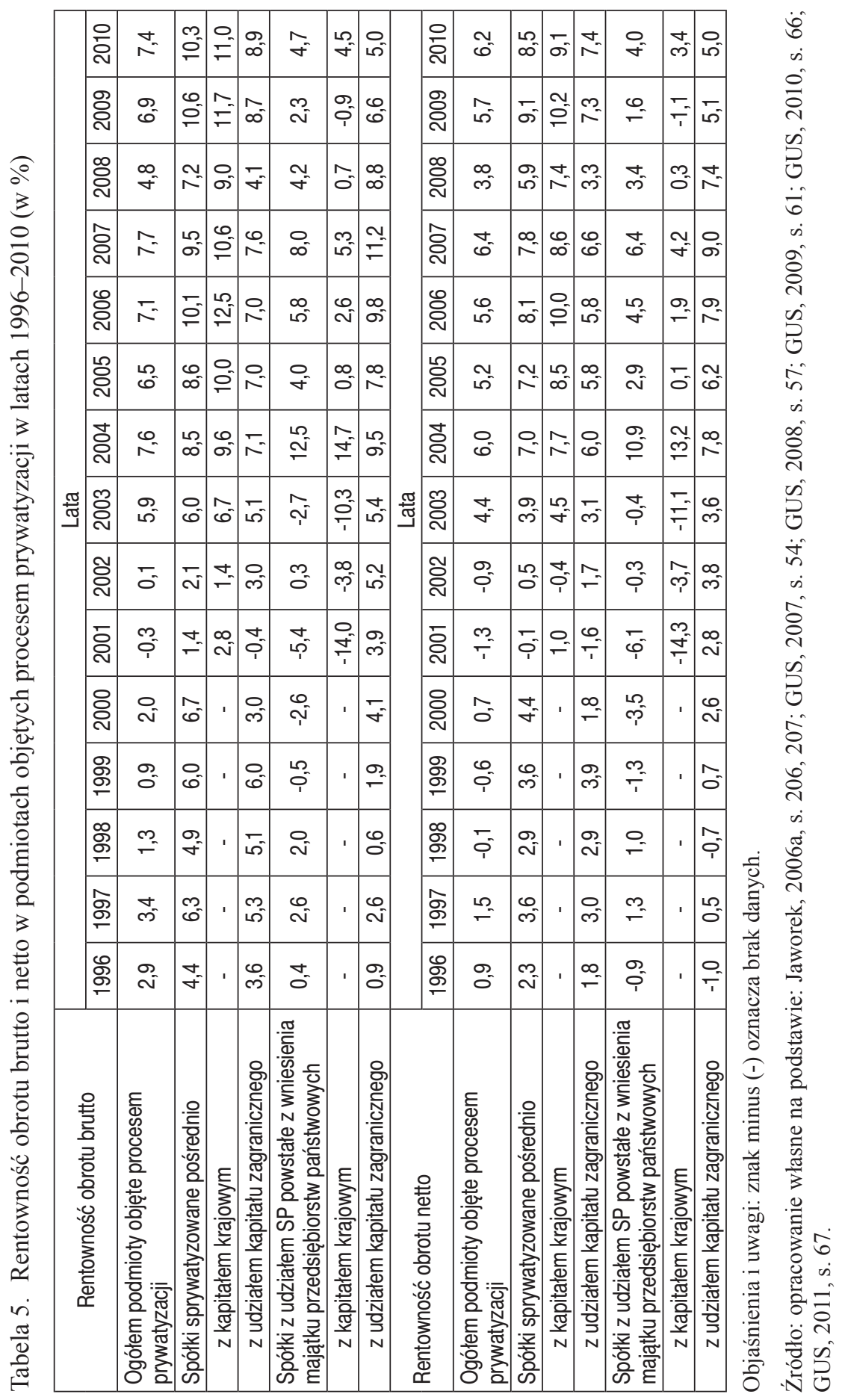


Podobnie wyglądała sytuacja w odniesieniu do wskaźnika rentowności obrotu netto. Lepiej „radziły” sobie przedsiębiorstwa sprywatyzowane z kapitałem polskim z wyjątkiem lat: 1998, 1999, 2002. Taka sytuacja nie jest zaskoczeniem, zważywszy na wyższe poziomy wskaźnika poziomu kosztów, jakie w badanym okresie wykazywały spółki przekształcone pośrednio z kapitałem zagranicznym.

$\mathrm{Na}$ uwagę zasługują dobre wyniki spółek powstałych $\mathrm{z}$ wniesienia majątku przedsiębiorstw państwowych do spółki z udziałem kapitału zagranicznego, w odniesieniu do wskaźnika rentowności obrotu brutto. W badanym okresie był on zdecydowanie większy w porównaniu ze spółkami z kapitałem polskim sprywatyzowanymi tym trybem, z wyjątkiem lat: 1997, 1998, 2004. Podmioty z udziałem kapitału zagranicznego w tej ścieżce prywatyzacji osiągały wyższe poziomy wskaźnika rentowności obrotu netto z wyłączeniem lat: 1996, 1997, 1998, 2004.

Zastanawiać może niższa rentowność, w analizowanym okresie, spółek sprywatyzowanych pośrednio z udziałem kapitału zagranicznego, mimo iż procesy restrukturyzacji były tam realizowane najbardziej kompleksowo i najgłębiej. Przyczyną mogła być strategia inwestorów, która nastawiona była na rozwój i gruntowną restrukturyzację majątkową i produktową, a nie na szybkie uzyskanie zysku (Jaworek, 2006, s. 81-89; Krajewski, 1996, s. 151).

W analizowanym okresie, z wyjątkiem roku 2004, lepsze wyniki w zakresie rentowności obrotu netto uzyskiwały spółki sprywatyzowane pośrednio w porównaniu ze spółkami powstałymi z wniesienia majątku przedsiębiorstw państwowych, na co znaczny wpływ miały przedsiębiorstwa z kapitałem polskim (tabela 5).

\section{PODSUMOWANIE}

W analizowanym okresie, uogólniając, lepsze wyniki w odniesieniu do wskaźnika poziomu kosztów i płynności pierwszego stopnia osiągnęły spółki sprywatyzowane bezpośrednio z udziałem inwestorów zagranicznych aniżeli spółki z ich udziałem sprywatyzowane pośrednio. Podmioty sprywatyzowane bezpośrednio z udziałem inwestorów zagranicznych, w latach 2000-2008, wykazywały wyższe poziomy wskaźnika rentowności zarówno brutto, jak i netto aniżeli spółki sprywatyzowane pośrednio z kapitałem zagranicznym.

Jeśli za kryterium analizy przyjąć udział kapitału zagranicznego, to należy stwierdzić, iż lepiej radziły sobie, w ścieżce prywatyzacji bezpośredniej, podmioty z udziałem inwestorów zagranicznych. Uogólniając, w badanym okresie 
wykazywały one niższe poziomy wskaźnika poziomu kosztów, wyższe poziomy wskaźnika płynności pierwszego stopnia oraz wyższe poziomy wskaźnika obrotu brutto i netto. W grupie przedsiębiorstw sprywatyzowanych bezpośrednio z udziałem inwestorów zagranicznych więcej podmiotów osiągało zysk brutto i netto aniżeli tych przekształconych z kapitałem polskim. Gorzej „,rodziły” sobie spółki sprywatyzowane pośrednio z udziałem kapitału zagranicznego w porównaniu z podmiotami przekształconymi przy udziale kapitału polskiego. Mimo iż więcej podmiotów sprywatyzowanych pośrednio z udziałem kapitału zagranicznego wykazywało zysk, wskaźniki rentowności brutto i netto kształtowały się na niższym poziomie $\mathrm{w}$ porównaniu $\mathrm{z}$ przedsiębiorstwami sprywatyzowanymi tą ścieżką z kapitałem krajowym. Podmioty z kapitałem zagranicznym wykazywały równiej wyższe poziomy wskaźnika poziomu kosztów. W badanym okresie tylko w odniesieniu do wskaźnika płynności pierwszego stopnia sytuacja w tych podmiotach wyglądała korzystniej w porównaniu z podmiotami przekształconymi w tej ścieżce $\mathrm{z}$ kapitałem polskim.

\section{LITERATURA}

GUS (2007), Prywatyzacja przedsiębiorstw państwowych w 2006 roku, Warszawa. GUS (2008), Prywatyzacja przedsiębiorstw państwowych w 2007 roku, Warszawa. GUS (2009), Prywatyzacja przedsiębiorstw państwowych w 2008 roku, Warszawa. GUS (2010), Prywatyzacja przedsiębiorstw państwowych w 2009 roku, Warszawa. GUS (2011), Prywatyzacja przedsiębiorstw państwowych w 2010 roku, Warszawa. Jaworek M. (2006a), Bezpośrednie inwestycje zagraniczne w prywatyzacji polskiej gospodarki, TNOiK, Toruń.

Jaworek M. (2006b), Zmiany w zakresie aktywności inwestycyjnej przedsiębiorstw po prywatyzacji z udziatem inwestorów zagranicznych, [w:] Nalepka A. (red.), Inwestycje i nieruchomości, Wydawnictwo Akademii Ekonomicznej w Krakowie, Kraków.

Krajewski M. (1996), Efekty ekonomiczne udziału kapitału zagranicznego w prywatyzacji, [w:] Jarosz M., Kapitał zagraniczny w prywatyzacji, Instytut Studiów Politycznych PAN, Warszawa.

MSP (2011), Raport o przekształceniach własnościowych w 2009 roku, Warszawa. 


\section{FINANCIAL SITUATION OF STATE OWNED ENTERPRISES PRIVATIZED WITH THE PARTICIPATION OF FOREIGN CAPITAL IN POLAND}

A b stract: This article presents the process of privatisation of state owned enterprises in Poland with the participation of foreign capital in the years 1990-2010. It contains information on the scope, dynamics and financial situation (in the years 1996-2010) of state owned enterprises privatized directly and indirectly with the participation of foreign capital. The article was developed on the basis of information on the privatisation processes coming from the databases of the Ministry of State Treasury and the Central Statistical Office (CSO). There are also used data from surveys on financial results of enterprises carried out by the CSO.

Keywords: process of privatisation of state owned enterprises, foreign capital, indirect (capital) privatisation, direct (capital) privatization. 